\title{
Hormonal therapy for ovarian dysfunctions in high-productive cows
}

\author{
Liliya Khamitova*, Roman Rudakov, Mariya Knyazeva, and Anastasiya Metlyakova
}

Izhevsk State Agricultural Academy, Izhevsk 426069, Russia

\begin{abstract}
The analysis was made of culling data in the farm of the Udmurt Republic. As a result, it was found that the animals are eliminated due to gynecological and limb diseases. They make up 19-24\% and 18-31\% respectively. Analyzing the results of gynecological clinical examination of cows, we found a predominance of ovarian diseases $32-36 \%$, as well as endometritis $28-30 \%$. The ovarian dysfunction progresses mostly. This can be attributed to an increase in the productivity of cows in the Udmurt Republic over the past 5 years from 5601 to $6250 \mathrm{~kg}$ per $1 \mathrm{cow}$. In connection with an increase in the incidence of ovaries, the calf yield per 100 cows decreases from 88 to $85 \%$. Causes of ovarian disease can be diseases of the birth and postpartum period. For the treatment of ovarian hypofunction, 3 schemes were used for anestral and reactive reproductive cycles. Often, the cause of ovarian hypofunction is uterine pathology; drugs that have a therapeutic effect on the uterus are included in the scheme.
\end{abstract}

\section{Introduction}

High productivity is accompanied by a violation of the reproductive function of cattle. Now this is the main problem of increasing animal productivity and the profitability of animal husbandry. From the barren cows of the economy, no offspring has been received; premature culling of cows occurs due to massive diseases of the uterus and ovaries. A large number of young cows are removed from the herd before costeffective use $[1,2]$.

The ovaries are a paired organ with generative and endocrine functions [3]. The ovary is a dynamic organ, and its structure in the reproductive period undergoes constant cyclic changes [4].

Ovarian hypofunction (Hypofunctio ovarii) is a disease characterized by a decrease in the hormonal activity of the ovaries, in which inferior reproductive cycles (areactive, anestral, alibid, anovulatory) or anaphrodisia are observed [5].

Research purpose: to develop a therapy system for ovarian hypofunction at the Rico-Agro farm in the Uvinsky district of the Udmurt Republic.

To achieve this goal, the following tasks have been developed:

- To study the prevalence of ovarian dysfunction in cows in a particular farm (clinical and instrumental research, ultrasound);

- To study the therapeutic efficacy of hormonal drugs for the treatment of ovarian hypofunction in cows;

- Develop treatment regimens.

\section{Materials}

The work was carried out on the basis of the farm of Rico-Agro, in the Udmurt Republic, Uvinsky district, the village of Porshur-Tuklya. The farm is a breeding factory and is engaged in the cultivation of cattle of black and motley breed.

The object of research is cattle, cows of black-motley breed, unborn cows with a service period of more than 60 days and a productivity of more than $6000 \mathrm{~kg}$ for 305 days of lactation.

Cows were selected by the method of pair-analogues according to the results of gynecological medical examination. They were selected according to the following characteristics: absence of reproductive cycles, violation of cycles, ovarian pathology.

To study the condition of animals on the farm, they used: retrospective, anamnestic, clinical research, including rectal research, ultrasound of the genital organs.

Animals for the experiment were selected for 10 animals with 2 and 3 calving and productivity of over $6000 \mathrm{~kg}$ for 305 days of lactation, as well as 5 heifers with a productivity of over 20 liters per day. The live weight of cows is over $550 \mathrm{~kg}$, and the first-calf is over $500 \mathrm{~kg}$.

\section{Results}

The farm contains 1646 heads of cattle of black and motley breed. Of these, 637 cows are cows. The average milk yield of cows for 305 days of lactation is $6250 \mathrm{~kg}$. The yield of live calves is $85 \%$. This indicator over 5 years amounted to more than $88 \%$.

The Rico-Agro enterprise raises cattle of the dairy direction of a black and motley breed. They use artificial

\footnotetext{
*orresponding author: dmhlf@mail.ru
} 
insemination of cows and heifers in a rectocervical way and sperm of outstanding bulls for milk productivity, mass fraction of fat and protein, which have categories for milk yield and mass fraction of fat. Sperm is acquired at specialized breeding enterprises.

Animals are kept in clean, dry, warm cowsheds with good lighting and ventilation. Cows have predominantly average fatness.

A stall-walking system is applied for keeping animals. Cattle are kept in rooms where both harness and free placement are used. Milking of animals takes place automatically in the milk pipeline on the ground and in the milking parlor on the installation. Manure is cleaned mechanically with a scraper conveyor.

From the main herd, cows are transferred to the maternity ward 10 to 20 days before calving. In the room, a leash is used, except for calving boxes, where animals are kept freely. Straw, hay are used as litter in the boxes. Boxes are disinfected after each calving, as are the stalls where new-born animals are located. Disinfection is carried out chemically after mechanical cleaning, during a passive exercise of animals daily.

Calves are kept for up to two days in calving with their mother, then transferred to a dispensary, and cows - to a group of animals after calving. Milking occurs using a machine in a milk line. Manure is removed using a scraper conveyor.

Preventive clinics in winter are located in a building divided into two parts - a barn and a calf. In summer, calves are kept in individual houses with walking yards. Animals are kept in this room for 20-30 days, then transferred to another calf, where animals are kept for up to 6 months. Milk calves are fed from a nipple drinker, and calves over 10 days of age - from a bucket. In the winter period, calves are kept in group cages of 5-6 animals each. Cleaning of litter and manure is carried out manually every day.

Animals up to 6 months old are kept in cages, in groups of 10-15 animals each. Feeding is carried out from group feeders twice a day - a substitute for whole milk, in free access are concentrates, hay, chalk; from 34 months old, they begin to add silage to the diet. Near the calf, there is a walking yard where passive exercise is carried out. Manure is cleaned manually and mechanically using a scraper conveyor.

The exercise is present in the main livestock, calves up to 6 months old, but in the winter-stall period they do not receive a full-fledged daily exercise, because the area of walking areas does not allow to drive out all animals every day. Newly born animals receive a daily passive exercise.

Silage-silage type of feeding is applied, feed is distributed using a mixer. Also, additives are used protein-mineral vitamin premix, selenium and kayod preparations, since the Udmurt Republic is located in the biogeochemical zone with the insufficient content of selenium and iodine in soils and water. Feeding in the winter-stall period is carried out twice a day. The total nutritional value of the diet of lactating cows averages 21.7 feed units. In the summer-pasture period, the diet of lactating cows includes: green mass, concentrates, salt and additives. For each liter of milk, $0.2 \mathrm{~kg}$ of concentrates are added to cows. Individual drinking bowls are used for drinking. In the chemical study of feed, the following results were obtained: hay and silage of the 1 st -2 nd class, haylage - the 2 nd class.

Table 1. Removing cows from the herd

\begin{tabular}{|c|c|c|c|c|c|}
\hline \multirow{2}{*}{ Causes } & \multicolumn{5}{|c|}{ year } \\
\cline { 2 - 6 } & 2014 & 2015 & 2016 & 2017 & 2018 \\
\cline { 2 - 6 } & $\%$ & $\%$ & $\%$ & $\%$ & $\%$ \\
\hline $\begin{array}{c}\text { Low } \\
\text { productivity }\end{array}$ & 22.2 & 19.6 & 20.7 & 21.0 & 15.6 \\
\hline $\begin{array}{c}\text { Gynecological } \\
\text { diseases }\end{array}$ & 20.4 & 19.6 & 19.0 & 21.0 & 23.9 \\
\hline $\begin{array}{c}\text { Diseases of the } \\
\text { extremities }\end{array}$ & 25.9 & 25.4 & 18.5 & 30.9 & 28.1 \\
\hline Trauma & 7.4 & 9.8 & 6.9 & 4.9 & 6.2 \\
\hline Udder diseases & 20.4 & 19.6 & 19.0 & 14.8 & 17.7 \\
\hline other diseases & 3.7 & 5.9 & 8.6 & 7.4 & 8.3 \\
\hline
\end{tabular}

Cows are often rejected on the farm due to limb diseases. Laminitis, arthritis and sprain of limbs were revealed. Cows with such diseases often have ovarian hypofunction and uterine atony, and as a result the absence of reproductive cycles. This results from the inactivity of the animal.

For various reasons, gynecological diseases arise that prevent estrus, ovulation and conception in the first phase of development. The drugs used in the treatment of ovarian hypofunction are necessary for the full restoration of their function.

Surfagon is a hormonal drug, which contains the active substance luliberin acetate. It acts on the cells of the anterior pituitary gland, quickly reaching the maximum concentration in the blood. It is necessary to accelerate the maturation of follicles in the ovaries.

Fertagon is a hormonal drug containing in its composition such active substances as dalargin and alarelin acetate. Dalargin weakens the effect of stress on the body, and meanwhile, allarelin acetate stimulates follicular maturation and ovulation.

Estrofan is a prostaglandin that has a luteolytic effect on the corpus luteum of the ovaries, thereby reducing the amount of progesterone, which inhibits the growth of follicles.

Drugs exert their effect directly on the growth and development of follicles, while the effect on the uterus is very low or absent altogether. Due to the fact that postpartum complications, endometritis, atony and uterine subinvolution are a common cause of ovarian hypofunction, it is necessary to prevent these causes of the disease. Analysis of table 1 confirms the presence of these diseases.

There are problems on the farm: retention of the placenta, endometritis, subinvolution, atony of the uterus. On average, the retention of the placenta in a cow lasts 5-7 days and then when the cervix is opened, it is removed and treatment of endometritis begins.

In order to prevent retention of the placenta 6 hours after calving, cows are injected, depending on body weight, $2-3 \mathrm{ml}$ of estrofan. To improve the recovery period, cows are fed energy shakes. In addition, in the 
first days after calving, cows are fortified with tetravit in a dose of $10 \mathrm{ml}$.

Immediately after removal of the placenta, the cows are given an intrauterine foam-forming tablet called «Enroflon», they are repeated every other day, and then treatment of the catarrhal-purulent endometritis is started by introducing the drug «Floxavet» into the uterine cavity, this procedure is repeated 3 times every other day.

Thus, the cow that has undergone this course of treatment in full by the 20th day after calving, recovered in $80 \%$ of cases. The remaining animals in the amount of $20 \%$ more often go into the chronic form of the course of endometritis. Of the obvious forms of endometritis, purulent-catarrhal prevails. It manifests itself with abundant purulent efflux from the genitals.

For the treatment of latent forms of uterine diseases, drugs are needed that provide a therapeutic effect, as well as increase its tone and contribute to the full passage of all stages of the sexual cycle.

For this experiment, drugs acting on the myometrium were selected: «Metrostim» and «Metrilong».

Metrostim, which includes carbacholine, briefly enhances the contraction of the smooth muscles of the uterus. The metrilong containing propranolol in the composition promotes the manifestation of the activity of endogenous oxytocin, thereby exerting a contracting effect on the smooth muscles of the uterus. Chitosan and glycerin, which are part of it, have a prolonging effect of propranolol.

Obstetric and gynecological medical examination is carried out on 15, 30 and 45 days after calving, in order to timely detect diseases of the reproductive system and conduct fruitful insemination the first time. Insemination of cows is carried out no earlier than 60 days after calving. The heifers are inseminated at the age of 15 months, upon reaching a live weight of not less than $360 \mathrm{~kg}$.

There is no exercise on the farm, so the restoration of cows after calving forces the use of uterine-reducing drugs for a long time. At the same time, there is no highquality feed base, with year-round feeding of silos and haylage.

In the stall, sexual hunting is determined by changing the behaviour of the animal and the presence of outflows from the genitals. Before insemination, the spotted cow is checked rectally with an ultrasound scanner or by palpation for the presence and size of the follicle. The insemination technician conducts artificial insemination of cows in the rectocervical method, in the presence of a mature follicle. Cows are inseminated with sperm after thawing, as well as with a sexed seed, to increase the breeding stock of cows.

Thus, when developing these treatment regimens, we took into account the need for a combination of drugs for an integrated approach to treating ovarian hypofunction and increasing the reproductive ability of cows on the farm.

The production indicators of animals in the experiment are presented in table 2.

In connection with increasing the productivity of animals, problems with the reproductive ability of cows begin. This is evidenced by the annual decrease in calf yield. It is also worth noting a sharp jump in the disposal of cows from $10-12$ to $15 \%$.

Gynecological diseases are one of the common causes of cows dropping out of the herd for several years, they occupy almost a third of all causes.

A significant number of cows are prone to ovarian disease. Sick animals are of different ages.

Table 2. Degree of damage to animals by gynecological diseases

\begin{tabular}{|c|c|c|c|c|c|c|}
\hline \multirow{2}{*}{$\begin{array}{c}\text { Groups } \\
\text { of } \\
\text { animals }\end{array}$} & \multicolumn{6}{|c|}{$\begin{array}{c}\text { service period (days), } \\
\text { productivity (kg) }\end{array}$} \\
\cline { 2 - 7 } & 3 lactation & \multicolumn{2}{|c|}{ 2 lactation } & \multicolumn{2}{|c|}{ 1 lactation } \\
\hline 1 & 110, & 180, & 149, & 235, & 138 & 123 \\
& 6815 & 7358 & 6873 & 6102 & & \\
\hline 2 & 112, & 212, & 161, & 214, & 135 & 131 \\
& 7436 & 7108 & 6007 & 7234 & & \\
\hline 3 & 128, & 167, & 168, & 208, & 141 & 136 \\
& 7218 & 7954 & 7215 & 6418 & & \\
\hline the & 114, & 187, & 156, & 228, & 144 & 130 \\
control & 7087 & 6984 & 6352 & 7123 & & \\
\hline
\end{tabular}

Table 3. Degree of damage to animals by gynecological diseases

\begin{tabular}{|l|c|c|c|c|c|}
\hline \multirow{2}{*}{ Indicators } & \multicolumn{5}{|c|}{ Years } \\
\cline { 2 - 6 } & 2014 & 2015 & 2016 & 2017 & 2018 \\
\hline $\begin{array}{l}\text { gynecologically sick, } \\
\text { total: heads (\%) }\end{array}$ & 277 & 298 & 302 & 372 & 390 \\
$(100)$ & $(100)$ & $(100)$ & $(100)$ & $(100)$ \\
\hline $\begin{array}{l}\text { of hich: endometritis } \\
\text { heads (\%) }\end{array}$ & 79 & 85 & 91 & 107 & 108 \\
retention of & $(28)$ & $(29)$ & $(30)$ & $(29)$ & $(28)$ \\
$\begin{array}{l}\text { membranes fetal heads } \\
(\%)\end{array}$ & 71 & 74 & 79 & 98 & 91 \\
& $(26)$ & $(25)$ & $(26)$ & $(26)$ & $(23)$ \\
\hline $\begin{array}{l}\text { ovarian disease, } \\
\text { heads (\%) }\end{array}$ & 94 & 99 & 95 & 124 & 142 \\
\hline $\begin{array}{l}\text { other gynecological } \\
\text { diseases, heads (\%) }\end{array}$ & $33)$ & $(33)$ & $(32)$ & $(33)$ & $(36)$ \\
\hline
\end{tabular}

Table 3 shows the annual growth of ovarian disease. They occupy a third of all other gynecological diseases. The most common diseases of the ovaries are hypofunction of the ovaries and follicular cysts (Table 4).

The main etiological factors that provoked the development of ovarian hypofunction are the lack of exercise in the postpartum period, and its incomplete provision, especially in the winter - stall period, as well as intensive exploitation of animals $[6,7,8]$.

The exercise has a positive effect on the cardiovascular, respiratory, digestive, sexual and musculoskeletal systems of cows [9]. Under conditions of physical inactivity, most animals after childbirth remain with impaired sexual function and infertile [10].

Table 4. Degree of damage to cows by ovarian disease

\begin{tabular}{|c|c|c|c|c|c|}
\hline $\begin{array}{c}\text { Ovarian Diseases / } \\
\text { unit of measurement }\end{array}$ & 2014 & 2015 & 2016 & 2017 & 2018 \\
\hline follicular cyst heads & 28 & 31 & 29 & 37 & 40 \\
\hline luteal cyst heads & 13 & 16 & 17 & 20 & 21 \\
\hline Hypofunction, heads & 26 & 25 & 26 & 38 & 46 \\
\hline Atrophy of the ovaries, heads & 2 & 1 & 4 & 3 & 3 \\
\hline $\begin{array}{c}\text { persistent corpus luteum, } \\
\text { heads }\end{array}$ & 21 & 26 & 19 & 26 & 32 \\
\hline
\end{tabular}


According to the results of an obstetric-gynecological study, 24 animals with a presumptive diagnosis of ovarian hypofunction were selected. Two animals of the first, second and third lactation were selected for the study.

Ovarian therapy in the household was previously carried out with standard drugs. For the treatment of follicular cysts, surfacton was used in a dose of $5 \mathrm{ml}$ for 3 days, and for the treatment of hypofunction of the ovaries, the follimage was administered once in a dose of
$1000 \mathrm{IU}$, and on day 14, estrofan in a dose of $2 \mathrm{ml}$. But, due to the fact that the follimage does not give the expected results, it is necessary to develop a new treatment regimen for ovarian hypofunction.

The developed treatment regimens for ovarian hypofunction are presented in table 5. These regimens are used for different forms of ovarian hypofunction. Scheme No. 1 and No. 2 are with anestral or arrhythmic sexual cycle; scheme No. 3 is with a full and rhythmic sexual cycle. The old treatment regime was used as a control.

Table 5. Treatment regimens for ovarian hypofunction

\begin{tabular}{|c|c|c|c|c|c|c|}
\hline $\begin{array}{c}\text { Scheme } \\
\text { №№ }\end{array}$ & 7 day cycle & 14 day cycle & 18 day cycle & 21 day cycle & $\begin{array}{c}\text { lack of a hunting } \\
\text { stage }\end{array}$ & 18 day cycle \\
\hline 1 & $\begin{array}{c}\text { metrostim, } 2 \mathrm{ml}, 3 \\
\text { times in one day }\end{array}$ & $\begin{array}{c}\text { Surfagon } \\
10 \mathrm{ml} 3 \text { days }\end{array}$ & $\begin{array}{c}\text { estrofan } \\
2 \mathrm{ml} \text { once }\end{array}$ & insemination & $\begin{array}{c}\text { estrofan } \\
2 \mathrm{ml} \text { once }\end{array}$ \\
\hline 2 & $\begin{array}{c}\text { metrilong, } \\
10 \mathrm{ml} \text { once }\end{array}$ & $\begin{array}{c}\text { Fertagon } \\
10 \mathrm{ml} 3 \text { days }\end{array}$ & $\begin{array}{c}\text { estrofan } \\
2 \mathrm{ml} \text { once }\end{array}$ & insemination & & $\begin{array}{c}\text { estrofan } \\
2 \mathrm{ml} \text { once }\end{array}$ \\
\hline 3 & $\begin{array}{c}\text { metrostim, } 2 \mathrm{ml}, 3 \\
\text { times in one day }\end{array}$ & $\begin{array}{c}\text { Surfagon } \\
10 \mathrm{ml} 3 \text { days }\end{array}$ & - & $\begin{array}{c}\text { Surfagon, } 10 \mathrm{ml} \\
1 \text { hour before } \\
\text { insemination }\end{array}$ & & - \\
\hline the control & $\begin{array}{c}\text { follimag, } 1000 \\
\text { IU, once }\end{array}$ & $\begin{array}{c}\text { estrofan } \\
2 \text { ml once }\end{array}$ & - & - & & - \\
\hline
\end{tabular}

Table 6. Ultrasound Results

\begin{tabular}{|c|c|c|c|c|}
\hline \multirow[t]{2}{*}{ 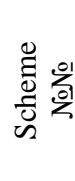 } & $\begin{array}{c}38 \text { days after } \\
\text { the first } \\
\text { insemination, } \\
\text { heads }\end{array}$ & $\begin{array}{c}38 \text { days after } \\
\text { the second } \\
\text { insemination, } \\
\text { heads }\end{array}$ & \multirow[t]{2}{*}{$\begin{array}{c}\text { Not pregnant } \\
60 \text { days after } \\
\text { insemination, } \\
\text { heads }\end{array}$} & \multirow[t]{2}{*}{$\begin{array}{l}\text { no } \\
\text { sex } \\
\text { hunt, } \\
\text { heads }\end{array}$} \\
\hline & \multicolumn{2}{|c|}{ pregnant cows, heads } & & \\
\hline 1 & 5 & - & 1 & - \\
\hline 2 & 2 & 1 & 2 & 1 \\
\hline 3 & 5 & - & 1 & - \\
\hline
\end{tabular}

Ultrasound, in table 4 , shows the positive dynamics of therapy according to schemes No. 1 and No. 3. $80 \%$ of the tested animals according to these schemes became fruitful after the first insemination.

Gynecological diseases are very common in the reproduction of a herd of black-motley cattle. The farm "Rico-Agro" is no exception and has very high rates of incidence of cows in gynecology, and accordingly, the rates of reproduction are reduced. So from 2014 to 2018, culling for gynecological diseases progressed from 20.4 to $23.9 \%$, and ovarian diseases increased from 33-34 to $36 \%$ over the past year. Based on this, the calf yield per 100 cows decreased from 88 to $85 \%$.

The main reasons for the decrease in reproductive ability are inflammatory processes of the genitals, lack of exercise, high productivity, lack of trace elements, violation of animal health standards, unbalanced diets, which violates metabolism, lack of energy, and a long stall period.

Thus, using treatment regimens No. 1 and 3, which include drugs such as Metrostim, Surfagon and Estrofan, we found high rates of cow fertilization from the first insemination. This indicator was $80 \%$. The use of new treatment regimens will help the farm to bring reproduction to a new level, with an intensive increase in indicators for artificial insemination of cows, a reduction in the service period and the insemination index.

\section{Conclusion}

High rates of milk productivity are increasingly accompanied by a malfunction of the reproductive system of cattle. This problem reduces the economic performance of production. Diseases of the ovaries and uterus are massive. Young cows are heavily rejected for cost-effective use. Ovarian hypofunction (Hypofunctio ovarii) is a dysfunctional disease characterized by a decrease in the hormonal activity of the ovaries, in which inferior reproductive cycles are observed, including the reactive and anestral forms. Complex therapy in the initial stage of the disease against the background of balanced feeding and improvement of the living conditions has a beneficial therapeutic effect. As a result of the experiment, positive dynamics with identical results were obtained using scheme No. 1 in the reactive cycle and scheme No. 3 in the anestral cycle. In general, fertilization occurred during the first insemination in 5 out of 6 cows. The preparation Metrostim (the active substance is carbacholine) has a restoring effect on the myometrium, and Surfagon, a synthetic analogue of $\mathrm{GnRH}$, has a gonadotropic effect.

\section{References}

1. L.V. Madoz, M.J. Giuliodori, A.L. Migliorisi, M. Jaureguiberry, R.L. de la Sota, Endometrial cytology, biopsy, and bacteriology for the diagnosis of subclinical endometritis in grazing dairy cows, J. Dairy Sci., 97(1), 195-201 (2014)

2. J. Stevenson, Eleven truths about ovarian cysts, Hoard's Dairyman, The National Dairy Farm Magazine, 21 (January 2012) 
3. A.M. Batista, D.M. Silva, M.J. Rego, F.L. Silva, E.C. Silva, The expression and localization of leptin and its receptor in goat ovarian follicles, Anim. Reprod. Sci., 141, 142-147 (2013)

4. D. Scheetz, K. Joseph Forger, G.W. Smith, Granulosa cells are refractory to FSH action in individuals with a low antral follicle count, Reproduc., Fertil. and Developm., 24, 327-336 (2012) DOI: org/ 10.1071/RD11020

5. F.O. Ahmed, A.S. Elsheikh, Uterine bacterial infection during postpartum delays the recrudescence of the reproductive traits in dairy cows, J. of Americ. Sci., 9(6), 596 (2013)

6. N. Forde, M.E. Beltman, P. Lonergan, M. Diskin, J.F. Roche, Oestrous cycles in Bos Taurus cattle, Anim. Reprod. Sci., 124, 163-169 (2011)
7. D. Vuković, B. Stančić, A. Božić, Review of the dairy cows herd efficiency based on reproductive parameters, in Proc. of 23rd Int. Symp. "New technologies in contemporary animal production," 69-71 (Novi Sad, Serbia, 19-21 June 2013)

8. I.M. Sheldon, E.J. Williams, A.N.A. Miller, D. M. Nash, S. Herath, Uterine diseases in cattle after parturition, The Veter. J., 176(1), 115-121 (2008)

9. W. Senosy, M. Uchiza, N. Tameoka, Y. Izaike, T. Osawa, Impact of ovarian and uterine conditions on some diagnostic tests output of endometritis in postpartum high-yielding dairy cows, Reproduct. in domestic anim., 46, 805 (2011)

10. F. Selami, G. Selami, Preliminary survey of the administration of $P G F 2 A$ in postpartum dairy cows, The Alban. J. of agricult. sci., 11(4), 229 (2012) 